\title{
Kam Lietuvoje laiduota (vietos) savivaldos teisė ir kaip ji igyvendinama?
}

\author{
Algirdas Astrauskas \\ Mykolo Romerio universitetas \\ Ateities g. 20, LT-08303 Vilnius, Lietuva \\ doi:10.13165/VPA-14-13-4-10
}

\begin{abstract}
Anotacija. Lietuvoje apie vietos savivalda paskelbta nemažai mokslo darbu. Vis dèlto mokslo darbu, kuriuose vietos savivalda bütu tyrinejama sistemiškai, dar labai trūksta. Šio straipsnio autorius yra nagrinejęs dauguma vietos savivaldos sistemos elementu ir vertinęs skirtingu laiku Lietuvoje pasireiškusia šios sistemos elementu specifika ir problematika. Pastaruosius keleta metu autorius rengia apibendrinamojo pobūdžio apžvalgas apie Lietuvos vietos savivaldos sistema ir jos kaitos dèsningumus per tam tikra istorini laikotarpi. Moksliniame leidinyje „Viešoji politika ir administravimas" autorius jau yra paskelbęs keleta straipsniu [2, 3], kuriuose per dangiau kaip dvidešimt metu sukauptu žiniu ir igytos asmeninès praktinès patirties teisèküros ir teisès aktu igyvendinimo procesuose pagrindu, pasinaudodamas kitu mokslininku vertingomis išvadomis ir pastebèjimais, pateikè savo požiürị i ịvairius vietos savivaldos sistemos elementus ir ju vertinimus. Šiame straipsnyje autorius toliau tęsia vietos savivaldos sisteminị nagrinejima ir, kūrybiškai pasinaudodamas analogija, pateikia savo požiūrị $i$ tai, kam Lietuvoje laiduojama (vietos) savivaldos teisé (t. y. kas yra (vietos) savivaldos teisés subjektas) ir kaip, autoriaus nuomone, ji igyvendinama.
\end{abstract}

Reikšminiai žodžiai: savivaldos teisè, vietos savivaldybès bendruomenè, vietos savivaldybè, vietos savivalda, savivaldos teisès igyvendinimas.

Keywords: self-government right, municipal community, municipality, local selfgovernment, implementation of self-government right.

\section{Ivadas}

Kam iš tikrųjų laiduota savivaldos teisè ir kaip ji realiai igyvendinama - tai klausimai, kurie kyla, kai svarstomi ir priimami su vietos savivalda susiję ịstaty- 
mai, kai konferencijų metu pasiekus diskusijos kulminaciją, prireikia ịvardyti tą subjektą, kuris Lietuvoje „turi Konstitucijos laiduotą savivaldos teisę“, taip pat paaiškinti, kaip ši teisè yra iš tikrųjų igyvendinama. Atrodytų, kad atsakymas slypi čia pat - pakanka tik atsiversti Lietuvos Respublikos Konstituciją, Europos vietos savivaldos chartiją ar Vietos savivaldos įstatymą arba surasti tam tikrus oficialiosios konstitucinès vietos savivaldos doktrinos, suformuluotos Lietuvos Respublikos Konstitucinio Teismo aktuose, teiginius. Tačiau įdèmiai susipažinus su šiais teisès šaltiniais ir sugretinus juose esančias teisines nuostatas ir/ar teiginius su teiginiais, randamais teisès teorijos, konstitucinės teisès, sociologijos, vadybos ir politologijos autoritetų darbuose, paaiškejja, kad aiškaus atsakymo visgi nèra. Autoriaus nuomone:

1) interpretuojant Lietuvos Respublikos Konstitucijos 119 straipsnio 1 dalies nuostatą „Savivaldos teisé laiduojama įstatymo numatytiems valstybès teritorijos administraciniams vienetams" nèra aiškaus atsakymo ị klausimą, kuriam iš subjektų Lietuvoje yra laiduojama (vietos) savivaldos teisè: valstybès teritorijos administraciniam vienetui? (Vietos) savivaldybès bendruomenei? (Vietos) savivaldybès atstovaujamajai institucijai?

2) aiškinant Lietuvos Respublikos Konstitucijos 119 straipsnio 1 dalies nuostatą „Savivaldos teise igyvendinama per atitinkamas savivaldybiu tarybas" kyla abejoniu, ar iš tiesu vienintelè (vietos) savivaldybės institucija, per kurią igyvendinama (vietos) savivaldos teisè, yra (vietos) savivaldybės taryba. Ką tuomet veikia (kam reikalingi) kiti (vietos) savivaldybės funkcijas atliekantys subjektai: vykdomoji institucija (vykdomosios institucijos), (vietos) savivaldybės administracija, (vietos) savivaldybės biudžetinès ar viešosios įstaigos arba kontroliuojamos įmonès?

Šio straipsnio tikslas - pateikti autoriaus požiūrị ị tai, kam Lietuvoje laiduojama (vietos) savivaldos teisè ir kaip (per kokius subjektus ir kokią veiklą vykdančius) ji yra įgyvendinama.

Tikslui pasiekti suformuluoti šie uždaviniai:

1) pateikti ir pakomentuoti nuostatas iš Lietuvos Respublikos Konstitucijos, Europos vietos savivaldos chartijos, Vietos savivaldos įstatymo, taip pat Lietuvos Respublikos Konstitucinio Teismo sprendimų dèl (vietos) savivaldos teisès laidavimo ir igyvendinimo;

2) taikant analogiją, nurodyti subjektą, kuriam, autoriaus nuomone, Lietuvoje yra laiduota (vietos) savivaldos teisé (t. y. nurodyti (vietos) savivaldos teisès subjektą);

3) atskleisti, kas ir kaip igyvendina (vietos) savivaldos teisę Lietuvoje.

\section{(Vietos) savivaldos teisès subjektas: ką nustato Lietuvos nacionaliniai ir tarptautiniai teisès aktai?}

Nuostatas dèl (vietos) savivaldos teisès laidavimo ir igyvendinimo randame Lietuvos Respublikos Konstitucijoje (toliau - Konstitucija) ir Lietuvos Respublikos Konstitucinio Teismo (toliau - Konstitucinis Teismas) nutarimuose ir sprendimuose, 
taip pat Lietuvos Respublikos vietos savivaldos ịstatyme (toliau - Vietos savivaldos istatymas) ir Europos vietos savivaldos chartijoje (toliau - Chartija) (3 straipsnyje). Svarbiausios nuostatos, kurios analizuojamos ir interpretuojamos šiame straipsnyje, yra pateiktos 1 lentelẻje. Sisteminè šių nuostatų analizè leidžia formuluoti šiuos teiginius (daryti šias išvadas):

1) (vietos) savivaldos teisès subjektu Lietuvoje gali būti laikomi net trys subjektai:

a) įstatymo nustatytas valstybès teritorijos administracinis vienetas, kuris Lietuvoje vadinamas savivaldybe (taip įrašyta Konstitucijos 119 straipsnyje);

b) įstatymo nustatyto valstybės teritorijos administracinio vieneto nuolatiniu gyventojų bendruomenè, kuri yra minima Konstitucinio Teismo aiškinamuosiuose teisès aktuose ir vadinama teritorine (arba vietos) bendruomene, savivaldybe, taip pat Vietos savivaldos įstatyme ir vadinama kiek kitaip - savivaldybes bendruome$n e$. Tačiau skirtumas slypi ne tik sąvokų pavadinimuose, bet ir giliau.

Atkreiptinas dėmesys ị tai, kad neaiškumų (dviprasmybių) nekelia ịstatymų leidèjo apibrèžta savivaldybès bendruomenès sąvoka (savivaldybès bendruomené tai žmonių visuma, susidedanti iš ịstatymo nustatyto valstybès teritorijos administracinio vieneto (savivaldybės) nuolatinių gyventojų, savivaldos teisiniais santykiais susijusių su savivaldybės taryba ir kitais viešojo administravimo funkcijas atliekančiais subjektais). Tačiau, autoriaus nuomone, Konstitucinio Teismo aktuose vartojamą sąvoką teritorine (arba vietos) bendruomene galima interpretuoti (aiškinti) dvejopai: ir taip, kaip apibrèžta savivaldybès bendruomenés sąvoka, ir visai kitaip - kaip socialinį darinį, sudarytą iš įstatymo nustatyto valstybès teritorijos administracinio vieneto nuolatinių gyventojų, susijusių tik kaimynystès ryšiais. $\mathrm{O}$ tai gali būti labai svarbu, norint suprasti, kas yra „tikrasis“" (vietos) savivaldos subjektas.

c) (vietos) savivaldybès atstovaujamoji institucija, Lietuvoje vadinama savivaldybés taryba, sudaryta iš slaptu balsavimu tiesioginių, lygių ir visuotinių rinkimų būdu laisvai išrinktų ịstatymo nustatyto valstybès teritorijos administracinio vieneto nuolatinių gyventojų, kaip nustato 1999 metais Lietuvos Respublikos Seimo be išlygų ratifikuota Chartija;

2) autoriaus nuomone, nèra aišku, kodèl oficialiosios konstitucinès vietos savivaldos doktrinos Lietuvoje kūrejjai (vietos) savivaldos teisès subjektu (t. y. subjektu, kuriam, jų nuomone, priklauso Konstitucijos laiduota (vietos) savivaldos teisè) pasirinko teritorinę (vietos) bendruomenę, nors pagal Konstitucijos teksto kūrèjų ir Valstybès Tautos referendume išreikštą valią (vietos) savivaldos teisė yra laiduota ịstatymo nustatytiems valstybès teritorijos administraciniams vienetams. Jiems derẻjo išaiškinti (vietos) savivaldos teisès subjekto - ịstatymo nustatyto valstybès teritorijos administracinio vieneto, sąvoką, o ne „savaip“ interpretuoti.

Atkreiptinas demesys, kad savo moksliniuose darbuose įstatymo nustatyto valstybès teritorijos administracinio vieneto sąvokos turinį yra atskleidęs Egidijus Šileikis. Jis, pateikęs korporacijos ir savivaldybès plačiaja prasme sąvokų apibrèž- 
tis, konstatavo, kad „siauraja prasme savivaldybès - tai valstybès teritorijos administraciniai vienetai, kurie, kaip teritorinès korporacijos, tenkina tam tikros teritorinès bendruomenès viešuosius poreikius savarankiškai pagal valstybès nustatytą kompetenciją“" [16, p. 260];

3) autoriaus nuomone, oficialiosios konstitucinès vietos savivaldos doktrinos kūrèjai (vietos) savivaldos teisès subjektu teritorinę (vietos) bendruomenę galèjo pasirinkti, pritaikę analogiją: Konstitucijoje nustatyta, kad suverenitetas priklauso Valstybès Tautai. Matyt todèl, jų nuomone, ir (vietos) savivaldos teisé analogiškai galètų (turètų) priklausyti panašiam ị Valstybès Tautą subjektui, bet tik esančiam kitame lygmenyje: t. y. ịstatymo nustatytų valstybės teritorijos administracinių vienetų bendruomenėms (teritorinėms arba vietos bendruomenėms), sudarytoms iš šių vienetų nuolatinių gyventojų. Tačiau ar nebuvo pamiršta, kad, be Valstybės Tautai priklausančio suvereniteto (ir Valstybės Tautos kaip suvereno, aukščiausios galios turètojo) teisès, valstybės teorijoje yra žinomas ir dar vienas suverenas - valstybe (Mykolo Romerio nuomone, valstybè - tai teritorinis organizuotas (korporacijos tipo), priverstinis, antrinis socialinis junginys [15]) bei valstybès (vidinis ir išorès) suverenitetas. Ir tai vẻlgi yra labai svarbu, nes leidžia daryti prielaidą, kad analogiškai gali egzistuoti ne vienas, bet keli (vietos) savivaldos teisės subjektai;

4) autoriaus nuomone, oficialiosios konstitucinès vietos savivaldos doktrinos kūrẻjai analogiją pritaikè ir dèl (vietos) savivaldos teisès ịgyvendinimo: darytina prielaida, kad negalėdami (ar nenorẻdami) atitrūkti nuo Konstitucijoje griežtai suformuluotos nuostatos, kad savivaldos teise igyvendinama per atitinkamas savivaldybiu tarybas, jie (vietos) savivaldos teisès igyvendinimą iš esmès sutapatino su aukščiausios valdžios vietos savivaldybėse vykdymu ir vykdymu vienu iš dviejų teorijoje žinomų galimų būdų, t. y. tik per atstovaujamąsias savivaldybių (savivaldos) institucijas - savivaldybių tarybas. Nežinia kodèl, bet minètoje doktrinoje nèra chrestomatinio teiginio, kad aukščiausia galia (valdžia) vietos savivaldybejje iš tikrųjų priklauso savivaldybès bendruomenei, tačiau Lietuvoje igyvendinama „ypatingai“" dèl Konstitucijoje nustatytų nuostatų: Lietuvoje ši savivaldybès bendruomenès teisè yra apribota - šią galią (valdžią) savivaldybès bendruomenè negali igyvendinti pati tiesiogiai (per sprendžiamąji referendumą, sprendžiamąji susirinkimą ir pan.), o tik per savo atstovaujamąją instituciją - savivaldybès tarybą;

5) be to, autoriaus nuomone, vadovaujantis teisinèmis nuostatomis, kad „savivaldybė yra viešasis juridinis asmuo“, kuris „,jam suteiktas teises ir pareigas igyvendina per savo organus“, galejo būti pabandyta taikyti ir (vietos) savivaldos teisès igyvendinimo analogiją: galgi įstatymo nustatytam valstybès teritorijos administraciniam vienetui (o iš tikrųjų - teritorinei viešajai korporacijai, teritorinei organizuotai viešojo juridinio asmens statusą ir valstybès nustatytą kompetenciją turinčiai bendruomenei) Konstitucijos laiduota (vietos) savivaldos teisė spręsti vietos reikalus yra igyvendinama per visus vietos savivaldybę sudarančius subjektus, atliekančius viešojo administravimo ir viešuju paslangu teikimo funkcijas, o ne tik per savivaldybès tarybą. 


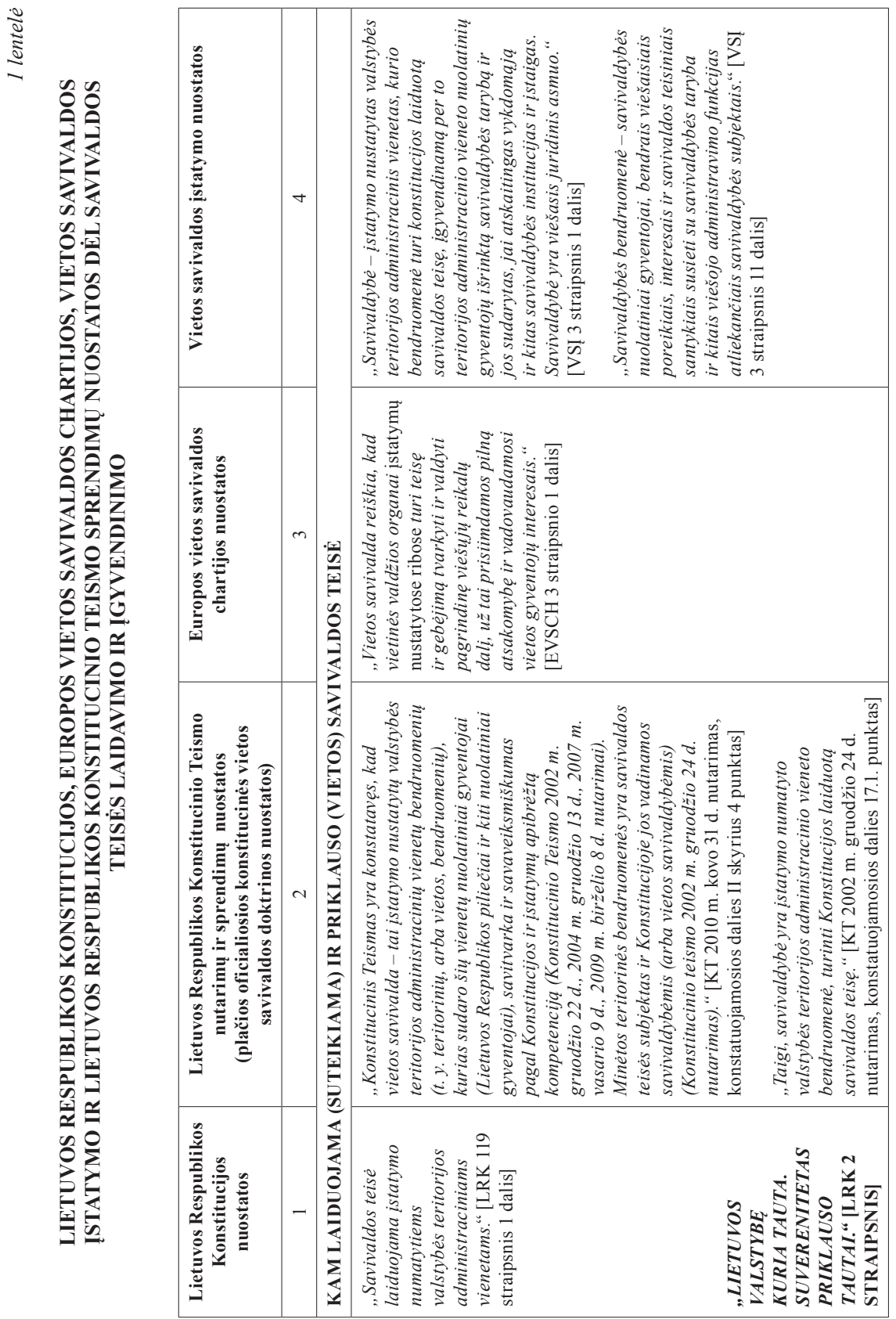




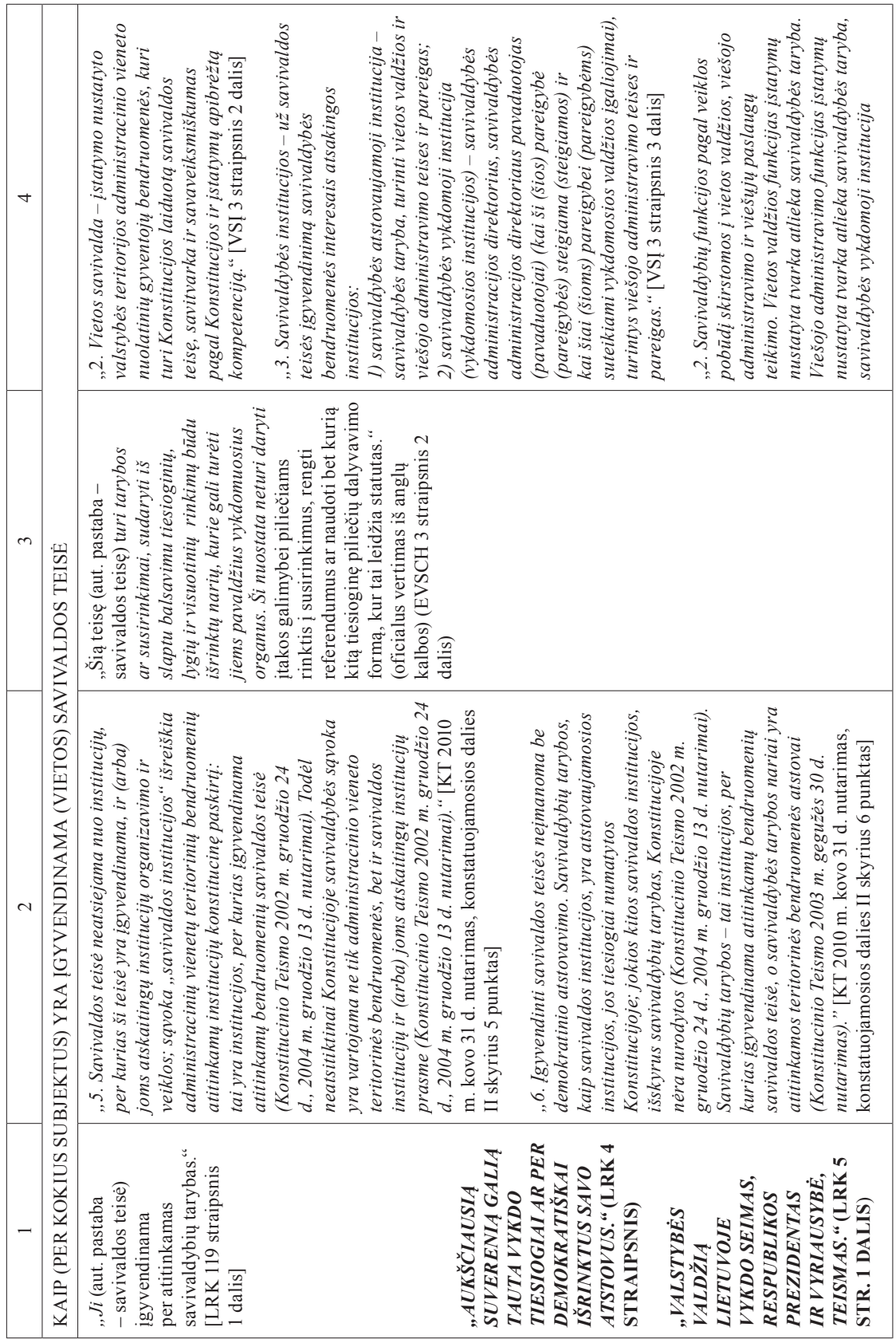




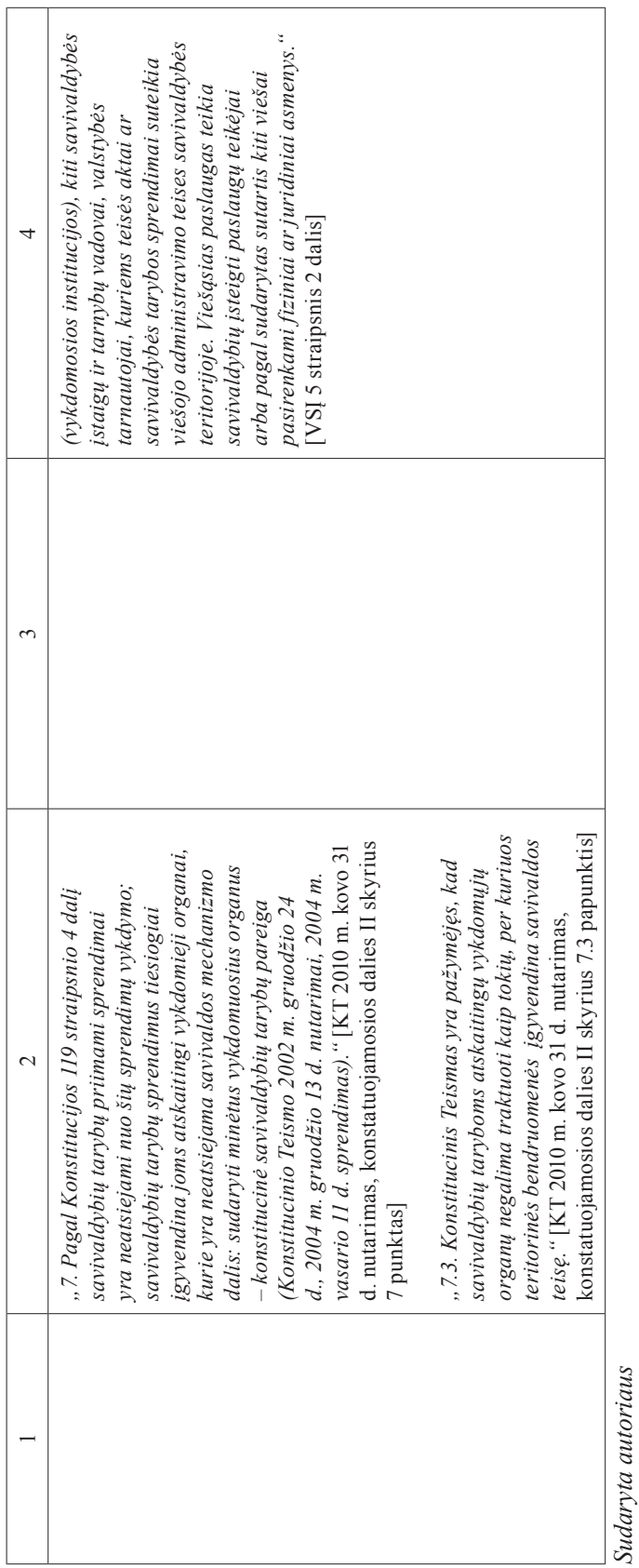




\section{Kam Lietuvoje laiduojama ir priklauso (vietos) savivaldos teisè?}

Teigtina, kad Lietuvoje, kuri priklauso šalims, kurių teisinė sistema kontinentinè ir kurioje, aiškinant vietos savivaldybių kilmę, vietos savivaldos esmę ir turinị, vadovaujamasi teisinès valstybės požiūriu ir dualinès vietos savivaldos teorija, teisè savarankiškai spręsti (tvarkyti) vietos reikalus (arba kitaip - (vietos) savivaldos teise platesne prasme) laiduojama vietos savivaldybei - iš istatymo nustatyto valstybès teritorijos administracinio vieneto (toliau - VTAV) nuolatiniu gyventoju sudarytam teritoriniam organizuotam viešojo juridinio asmens statusa ir valstybès nustatyta kompetencija turinčiam socialiniam junginiui (̌̌r. 1 paveikslą). VTAV nuolatiniai gyventojai iki vietos savivaldybės atsiradimo (o tiksliau - iki jos sukūrimo) gali egzistuoti dviem formomis:

1) juos dèl bendro gyvenimo ir (ar) pagrindinių interesų tenkinimo tam tikroje teritorijoje gali sieti, pasak M. Riomerio [15], nuolatiniai (t. y. tie patys ir nuolat besikartojantys arba skirtingi, bet vienijami vieno tikslo) socialinio bendravimo ryšiai ir dèl to (dèl juos siejančių tokio pobūdžio socialinio bendravimo ryšių) VTAV nuolatiniai gyventojai gali gyvuoti, anot vokiečių mokslininko F. Tonnie, kaip tam tikra neformalizuota teritorinè natūrali bendruomene [4],

2) tačiau VTAV nuolatiniai gyventojai gali, pasak M. Riomerio [15], būti susieti tik atsitiktiniais socialinio bendravimo ryšiais ir „būti matomi“ tik kaip mechanine žmoniu iš tam tikros teritorijos visuma.

Savivaldos teisés laidavimas (suteikimas) VTAV nuolatiniams gyventojams (kaip teritorinei natūraliai bendruomenei ar kaip tik atsitiktiniais socialinio bendravimo ryšiais susijusių žmonių mechaninei visumai) veikiau yra ne vienkartinis valstybès aktas, bet ilgesnị laika trunkantis procesas. Šio proceso metu vyksta ženklūs, kokybiniai pokyčiai VTAV nuolatiniu gyventoju gyvenime (tiksliau, jų bendravime, jų valdyme) ir valstybès priimamu sprendimu ir veiksmu dèka atsiranda (tiksliau - yra sukuriamas) iš VTAV nuolatinių gyventojų (kaip „mažiausių elementarių dalelių") sudarytas teritorinis organizuotas teisinị statusa ir valstybès apibrèžta kompetenciją turintis socialinis junginys. Ši socialinị junginį skirtingi mokslininkai vadina skirtingai: teritorinè socialinè organizacija (F. Tonnie [4]), teritorinis organizuotas (korporacijos tipo) socialinis junginys (M. Riomeris [15]), tikslo siekianti (organizacijos tipo) socialinè grupé (V. Legkauskas [7]), teritorinė korporacija (E. Šileikis [16]) ir pan. Toks socialinis junginys ir yra tas, kurị vadiname vietos savivaldybe.

Tam kad atsirastų (o tiksliau - būtų sukurtas) toks teritorinis organizuotas teisinị statusą ir valstybės apibrèžtą kompetenciją turintis socialinis junginys (vietos savivaldybè), valstybė turi priimti sprendimus ir atlikti tam tikrus veiksmus, kuriais:

1) būtų nustatytas tokio socialinio junginio dydis (gyventojų skaičius) ir teritorijos, kurioje gyvuos toks socialinis junginys, plotas bei ribos; 


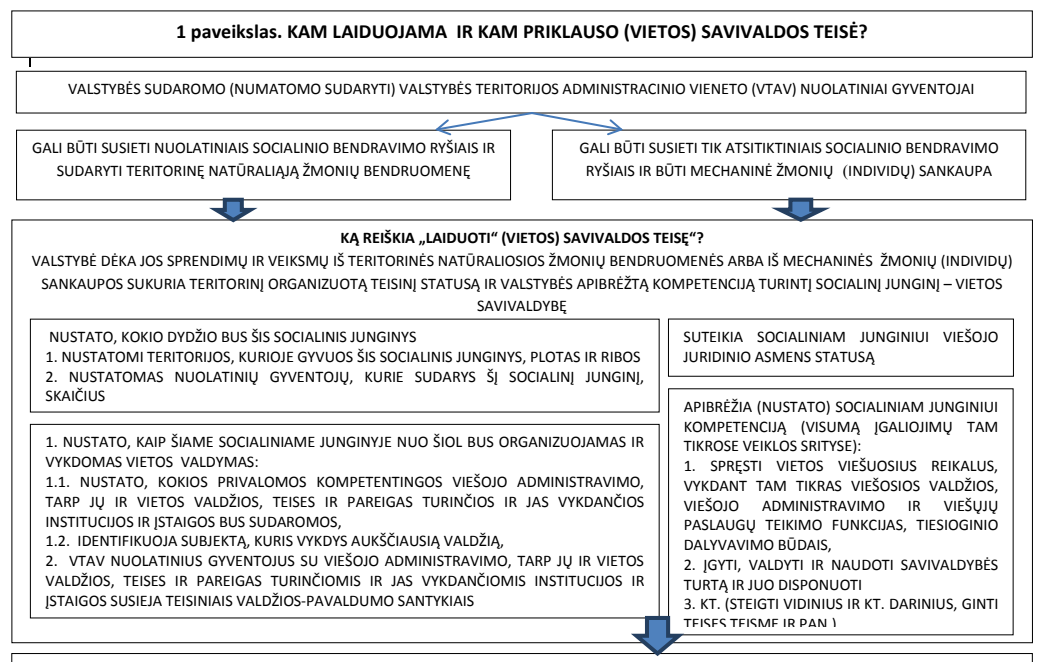

VIETOS SAVIVALDYBÉ - VALSTYBĖS SUKURTAS TERITORINIS ORGANIZUOTAS, TEISINİ STATUSĄ IR VALSTYBÉS NUSTATYTĄ KOMPETENCIJĄ TURINTIS SOCIALINIS DARINYS, GYVUOJANTIS TIKROJE APIBRÉŽTOJE TERITORIJOJE

\section{VIETOS SAVIVALDYBÉ}

\begin{tabular}{|c|c|}
\hline & \\
\hline SAVIVALDYBÉS (VTAV) TERITORIJA & $\begin{array}{l}\text { VIEŠOJO ADMINISTRAVIMO, TARP JŲ IR VIETOS VIEŠOSIOS VALDŽIOS, TEISES IR } \\
\text { PAREIGAS TURINČIOS IR JAS VYKDANČIOS SAVIVALDYBÉS INSTITUCIJOS IR ISTAIGOS }\end{array}$ \\
\hline & $\downarrow \quad$ 爪 \\
\hline $\begin{array}{l}\text { SAVIVALDYBÉS STRUKTŪRINIAIS } \\
\text { ELEMENTAIS: }\end{array}$ & $\begin{array}{l}\text { SAVIVALDYBĖS BENDRUOMENĖ } \\
\text { (TEISINIAIS VALDŽIOS-PAVALDUMO SANTYKIAIS SU SAVIVALDYBĖS INSTITUCIJOMIS IR } \\
\text { [STAIGOMIS SUSIJUSIŲ VTAV NUOLATINIŲ GYVENTOJŲ KIEKYBINĖ GAUSYBĖ) }\end{array}$ \\
\hline
\end{tabular}
[STAIGOMIS SUSIJUSIŲ VTAV NUOLATINIŲ GYVENTOJŲ KIEKYBINÉ GAUSYBĖ)

SAVIVALDOS TEISĖ KAIP TEISĖ SAVARANKIŠKAI SPRESTII (TVARKYTI) VIETOS REIKALUS LAIDUOJAMA VIETOS SAVIVALDYBEI VIETOS SAVIVALDYBÉ - (VIETOS) SAVIVALDOS TEISÉS (PLATESNE PRASME) SUBJEKTAS
SAVIVALDOS TEISĖ KAIP TEISĖ VYKDYTI AUKŠČIAUSIA VALDŽIA, LAIDUOJAMA SAVIVALDYBĖS BENDRUOMENE

SAVIVALDYBÉS BENDRUOMENE் - (VIETOS) SAVIVALDOS TEISÉS (SIAURESNE PRASMEI SUBIEKTAS

\begin{tabular}{|c|c|c|}
$\begin{array}{c}\text { (VIETOS) } \\
\text { SAVIVALDOS } \\
\text { TEISĖS } \\
\text { SUBJEKTAS }\end{array}$ \\
VIETOS SAVIVALDYBÉ
\end{tabular}

\begin{tabular}{|c|c|c|}
\hline \multicolumn{3}{|c|}{ KAS IR KAIP [GYVENDINA SAVIVALDOS TEISĘ? } \\
\hline $\begin{array}{l}\text { (VIETOS) } \\
\text { SAVIVALDOS } \\
\text { TEISĖS } \\
\text { [GYVENDINI } \\
\text { MAS }\end{array}$ & $\begin{array}{l}\text { (VIETOS) SAVIVALDOS TEISĘ KAIP } \\
\text { AUKŠČIAUSIĄ VALDŽIĄ } \\
\text { IGYVENDINA (VYKDO) } \\
\text { SAVIVALDYBĖS BENDRUOMENĖ } \\
\text { PATI AR PER SAVIVALDYBĖS } \\
\text { TARYBĄ }\end{array}$ & 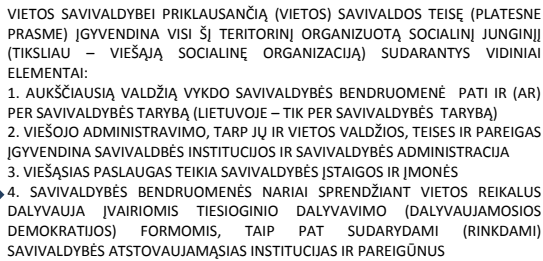 \\
\hline
\end{tabular}

\section{1 pav. Kam laiduojama ir kam priklauso (vietos) savivaldos teisé?}


2) būtų nustatyta, kaip šiame socialiniame junginyje nuo šiol bus organizuotas ir vykdomas vidaus valdymas: a) kokios privalomos kompetentingos vietos viešosios valdžios institucijos bus sudaromos, b) kuris subjektas vietos savivaldybeje vykdys aukščiausią valdžią (toks poreikis atsiranda, nes socialiniame junginyje vienu metu taikomos ne viena, bet kelios socialinès valdžios formos), c) VTAV nuolatiniai gyventojai su vietos valdžios subjektais susiejami teisiniais valdžiospavaldumo santykiais (teisèmis ir pareigomis). Šios naujai atsiradusių teisès aktais reguliuojamų socialinių ryšių (santykių) rūšies dèka VTAV nuolatiniai gyventojai igauna dar vieną gyvavimo formą: taip atsiranda savivaldybés bendruomenè - ypatingas šio socialinio junginio struktūrinis elementas;

3) tokiam teritoriniam ir organizuotam socialiniam junginiui yra suteikiamas viešojo juridinio asmens statusas ir tokiu būdu jis yra pripažįstamas kolektyviniu teisinių santykių dalyviu, galinčiu sueiti ị teisès aktais sureguliuotus visuomeninius santykius su kitais fiziniais ir juridiniais asmenimis, tarp jų ir su valstybe;

4) tokiam teritoriniam, organizuotam ir viešojo juridinio asmens statusą turinčiam socialiniam junginiui yra nustatoma (apibrėžiama) kompetencija (visuma teisiu ir pareigų tam tikrose veiklos srityse ir kiti kompetencijos elementai): a) spręsti (tvarkyti) priskirtus vietos (viešuosius) reikalus, vykdant vietos valdžios, viešojo administravimo ir viešųjų paslaugų teikimo funkcijas, b) igyti, valdyti, naudoti nuosavybės teise savivaldybės turtą ir juo disponuoti, c) sudaryti (steigti) vidinius ir kitus (ivvairaus teisinio statuso) darinius, ginti savo teises teisme ir kt. Kaip teigé M. Riomeris, valstybė ne su bet kuo, o būtent su tokiais organizuotais (turinčiais privalomas vietos viešosios valdžios institucijas, kurių sprendimų privalo klausyti VTAV nuolatiniai gyventojai - savivaldybės bendruomenès nariai) ir viešojo juridinio asmens statusą turinčiais teritoriniais socialiniais junginiais pasidalina visuomenès viešųjų reikalų tvarkymo naštą ir atsakomybę. Tos visuomenès viešųjų reikalų dalybos tarp valstybės ir vietos savivaldybių yra vadinamos politine decentralizacija arba tiesiog decentralizacija.

Taigi, po valstybės priimtų sprendimų ir veiksmų atsiradusi (o tiksliau - tikslingai kryptingų valstybės sprendimų ir veiksmų dẻka sukurta) vietos savivaldybė yra ne mechanine VTAV nuolatiniu gyventoju sankaupa, bet, priešingai - tam tikroje valstybės apibréžtoje teritorijos dalyje (VTAV teritorijoje) „savo gyvenimą pradedanti gyventi" teritorinè organizuota, teisinị statusa ir valstybès apibrëžta kompetencija turinti žmonių bendruomenè (teritorinè viešoji socialinè organizacija, teritorine viešoji korporacija ir pan.), sudaryta iš tarpusavyje susietų ir vienas nuo kito priklausančių struktūrinių makroelementų - savivaldybès viešosios valdžios (viešojo administravimo, tarp jų ir viešosios valdžios, teises ir pareigas turinčiu ir igyvendinančių institucijų ir ịstaigų) ir savivaldybès bendruomenès (visumos VTAV nuolatinių gyventojų, kurie teisiniais valdžios-pavaldumo santykiais yra susiję su savivaldybès viešosios valdžios institucijomis). Neretai teisinejje literatūroje prie vietos savivaldybės struktūrinių elementų priskiriamas dar ir trečias elementas - savivaldybés teritorija (VTAV teritorija). 
Kaip jau minèta, šiame minimame socialiniame junginyje ypatingas vaidmuo tenka jo elementui - savivaldybès bendruomenei, kuri tuo pat metu yra ir valdymo objektas, ir valdymo subjektas. Manytina, kad savivaldybės bendruomene kaip valdymo subjektas vietos savivaldybeje iš esmès atlieka panašu (bet ne tokị patị) vaidmeni kaip, anot $\mathrm{M}$. Riomerio, teritoriniame organizuotame (korporacijos tipo) priverstiniame, antriniame socialiniame junginyje - valstybejje atlieka Valstybės Tauta. Savivaldybės bendruomenè nuo Valstybès Tautos skiriasi tuo, kad savivaldybès bendruomené vietos savivaldybės nekuria, tuo metu teisè kurti valstybę priklauso būtent Valstybès Tautai.

Prisiminus, kad VTAV nuolatiniai gyventojai gali egzistuoti dviem formomis, vietos savivaldybe - teritorinis organizuotas teisinị statusą ir valstybès apibrèžtą kompetenciją turintis socialinis junginys gali atsirasti (o tiksliau - valstybès sprendimais ir veiksmais gali būti sukurtas) dviem būdais:

1) tai gali būti virsmas - kai teritorine natūralioji bendruomene (nuolatiniais socialinio bendravimo ryšiais susietų žmonių, nuolat gyvenančių tam tikroje teritorijoje, grupė) virsta teritorine organizuota teisinị statusą ir valstybės apibrèžtą kompetenciją turinčia žmonių bendruomene (tiksliau - teritorine viešąja socialine organizacija);

2) tai gali būti tapsmas - kai tam tikroje teritorijoje gyvenantys žmonės, kuriuos iki tol siejo tik atsitiktiniai socialinio bendravimo ryšiai, sutelkiami ị teritorinę viešąją socialinę organizacija (kuri, anot P. Zakarevičiaus [17], gali būti apibrèžiama ir kaip sudètinga, valdoma, tikslingai veikianti socialiné ekonominė sistema).

Norint atsakyti ị klausimą, kam iš tikrųjų laiduojama ir priklauso (vietos) savivaldos teisè (t. y. kas yra (vietos) savivaldos teisès subjektas), tikslinga kūrybiškai taikyti analogiją (žr. 2 paveikslą). Teisinejje literatūroje [18] yra skiriamas:

1) valstybès (vidinis ir išorinis) suverenitetas - tai valstybès (valstybiškai organizuotos žmonių bendruomenès) teritorinè viršenybe šalies viduje (jos politinès valdžios viršenybe ir nepriklausomumas nuo kitų valdžių valstybės teritorijoje) ir jos nepriklausomybe tarptautiniu santykiu požiüriu (teisinis nepriklausomumas nuo kitų valstybių ir kitokių išorinių socialinių veiksnių ir jëgų).

Šiuo atveju tai valstybei (valstybiškai organizuotai žmonių bendruomenei) priklausantis suverenitetas.

ir 2) Valstybès Tautos suverenitetas - tai valstybės piliečių visumos (pilietinès Tautos) kaip ypatingo valstybės struktūrinio elemento ir valstybinès valdžios šaltinio teisè ir galia kurti valstybę, pasirinkti vieną ar kitą valstybės formą, tam tikromis organizacinemis formomis (pvz., referendumas) tiesiogiai ar per savo demokratiškai išrinktą atstovybę vykdyti aukščiausią valdžią (galią) valstybèje.

Šiuo atveju suverenitetas (aukščiausios valdžios teisė) priklauso Valstybės Tautai. 


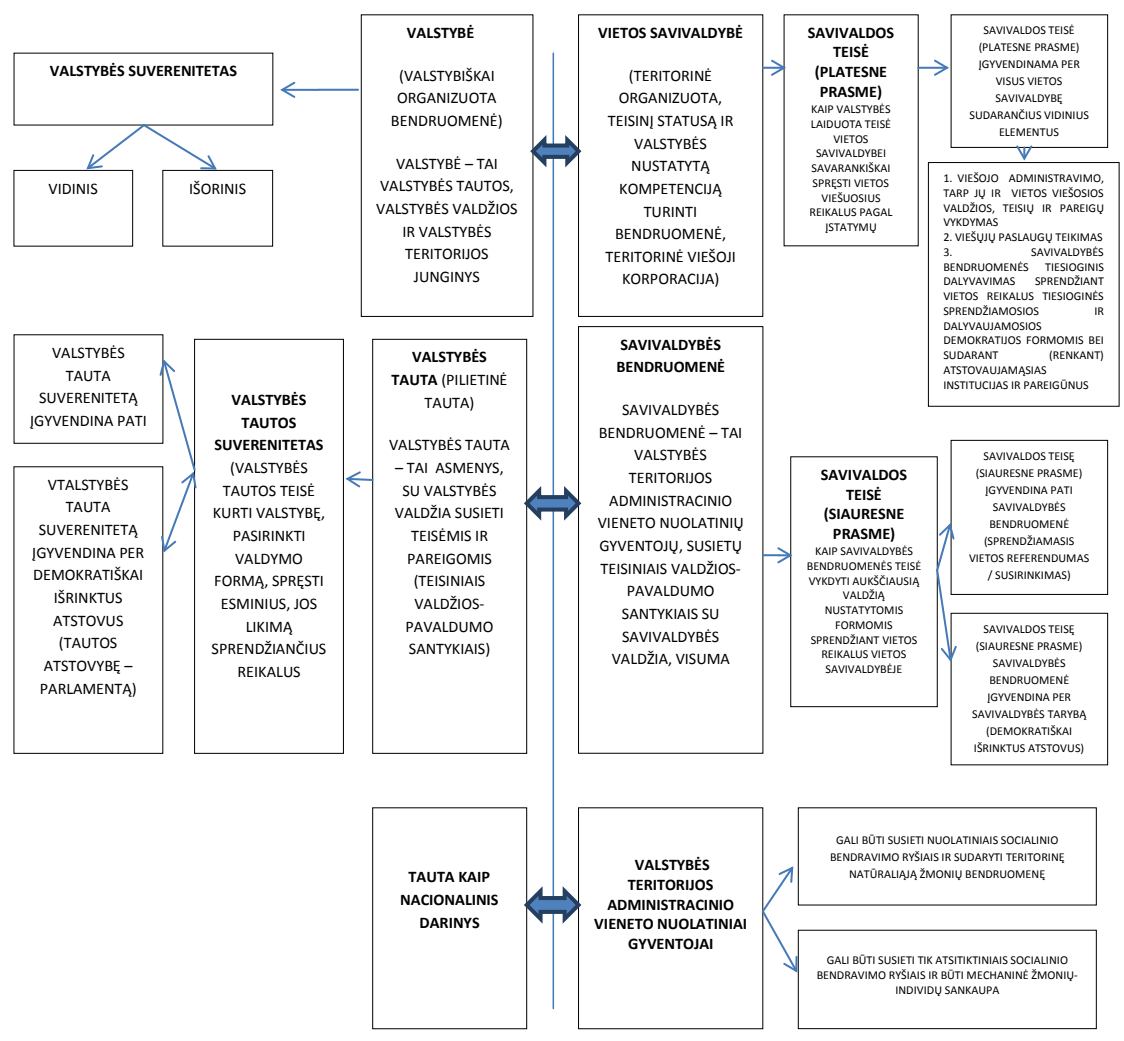

2 pav. Analogijos taikymas, aiškinant (vietos) savivaldos teisès subjektą ir šios teisès ịgyvendinimą

Todèl ir mūsų nagrinėjamu atveju turètų būti pripažisstama, kad gali būti:

ir 1) vietos savivaldybei priklausanti savivaldos teisè (vietos savivaldybès savivaldumas, (vietos) savivaldos teisè platesne prasme) - valstybès priimtų sprendimų dèka atsiradusio (sukurto) teritorinio organizuoto teisinị statusą ir valstybės apibrežtą kompetenciją turinčio socialinio darinio (vietos savivaldybès) teisè ir reali galia būti ir egzistuoti (reikštis) kaip teisiškai nepriklausomas (atskiras nuo kitų socialinių darinių), savivaldus (vykdantis vietos valdžią savivaldybėje per valstybès nustatyta tvarka, bet iš savivaldybès bendruomenès narių sudaromas savivaldybès (vietos valdžios) institucijas) ir savarankiškas (pagal valstybės (Konstitucijos, įstatymų, kitų teisès aktų) nustatytą kompetenciją savarankiškai sprendžiantis (tvarkantis) priskirtus vietos viešuosius reikalus, valdantis nuosavybės teise priklausanti turtą ir juo disponuojantis ir pan.) socialinis junginys. Šiuo atveju (vietos) savivaldos teisès (platesne prasme) subjektas yra visa vietos savivaldybè, 
ir 2) savivaldybès bendruomenei priklausanti savivaldos teise (savivaldybès bendruomenès savivaldumas, (vietos) savivaldos teisè siauresne prasme) - VTAV nuolatinių gyventojų, teisiniais valdžios-pavaldumo santykiais susijusių su vietos savivaldybès (vietos valdžios) institucijomis, kiekybinès gausybès (savivaldybès bendruomenès) kaip ypatingo vietos savivaldybès struktūrinio elemento teisè ir reali galia valstybès nustatytomis formomis tiesiogiai ar per vietos savivaldybès tarybą (vietos savivaldybès atstovaujamąją instituciją) vykdyti aukščiausią valdžią vietos savivaldybès teritorijoje, sprendžiant (tvarkant) vietos savivaldybès kompetencijai priskirtus vietos (viešuosius) reikalus. Šiuo atveju (vietos) savivaldos teise (aukščiausios valdžios vietos savivaldybëje teisè) priklauso savivaldybès bendruomenei, (vietos) savivaldos teisès (siauresne prasme) subjektas yra bütent savivaldybès bendruomene.

\section{Kas ir kaip įgyvendina (vietos) savivaldos teisę?}

Galima teigti, kad (vietos) savivaldos teisès igyvendinimas yra sietinas su subjektais, kuriems priklauso (vietos) savivaldos teisè, ir su tokių subjektų veikla, realizuojant jiems suteiktas teises ir pareigas (bei kitus kompetencijos elementus) tam tikrose veiklos srityse (̌̌r. 1 ir $\mathbf{3}$ paveikslus). Todèl teigtina, kad:

1) (vietos) savivaldos teisè kaip visai vietos savivaldybei (teritorinei organizuotai teisini statusa ir valstybès apibrěžtą kompetencija turinčiai bendruomenei) priklausanti teisè yra igyvendinama per visus ši sudètingą socialinị darinị sudarančius vidinius elementus ir pasireiškia kaip:

1.1) aukščiausios valdžios vykdymas (tai daro savivaldybès bendruomenè pati (tiesiogiai) nustatytomis organizacinèmis formomis ar per savivaldybès atstovaujamąją instituciją),

1.2) viešojo administravimo teisių ir pareigų vykdymas (tai daro savivaldybės atstovaujamoji (sprendžiamoji), vykdomoji (vykdomosios institucijos ir savivaldybės administracija), tarp jų:

1.2.1) vietos viešosios valdžios (vietos valdžios siauresne prasme) vykdymas (tai daro savivaldybès atstovaujamoji (sprendžiamoji) ir vykdomoji (vykdomosios institucijos),

1.2.2) viešojo administravimo funkcijų vykdymas (tai daro savivaldybès administracija),

1.3) viešųjų paslaugų teikimas (jas teikia savivaldybės biudžetinės ir viešosios įstaigos, savivaldybès ir (ar) jos kontroliuojamos įmonès),

1.4) tiesioginis dalyvavimas sprendžiant (tvarkant) vietos (viešuosius) reikalus (tai daro VTAV nuolatiniai gyventojai - savivaldybės bendruomenès nariai pavieniui ar jų grupès teisiškai ịtvirtintomis tiesioginès dalyvaujamosios demokratijos formomis ir nustatyta tvarka, taip pat rinkdami savivaldybės renkamąsias institucijas). 


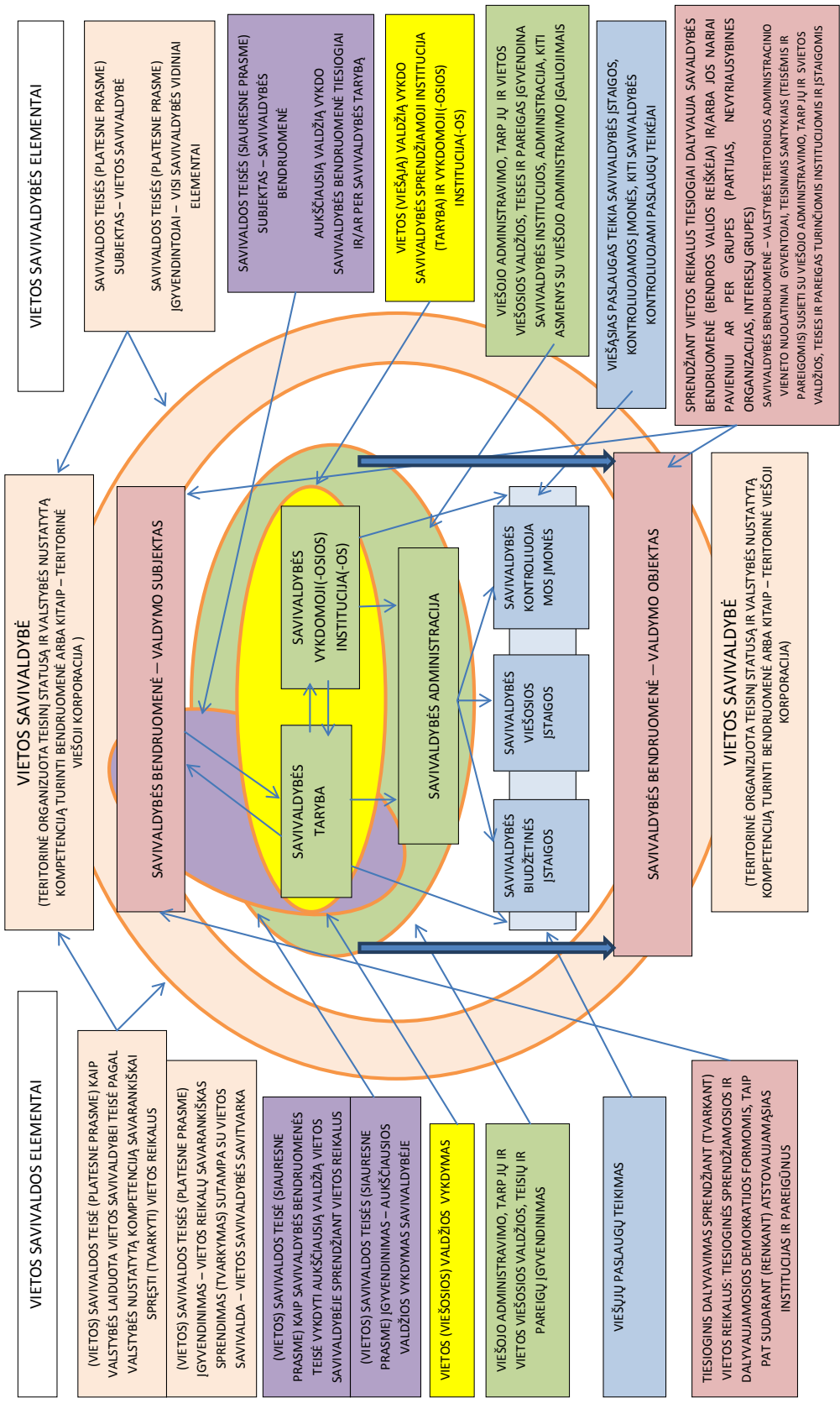

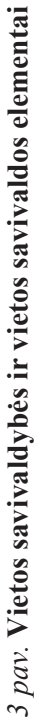


Šiuo atveju tarp (vietos) savivaldos teisès igyvendinimo ir vietos savivaldos (teritorinès organizuotos teisinị statusą ir valstybès apibrèžtą kompetenciją turinčios bendruomenès savitvarkos) galima dèti lygybès ženklą.

2) (vietos) savivaldos teise kaip savivaldybès bendruomenei priklausančia teisę vykdyti aukščiausia valdžia igyvendina savivaldybès bendruomene pati (tiesiogiai) arba per savivaldybès atstovaujamaja institucija - savavaldybès tarybą (asamblëją), sudaromą demokratinių rinkimų būdu. Kaip jau buvo minèta, valstybė, jau kurdama vietos savivaldybes, nustato ir kas (koks subjektas), ir kaip (kokiomis formomis, kokius vietos reikalus sprendžiant) vykdys aukščiausią valdžią vietos savivaldybejje. Nors gali pasirodyti keista, tačiau valstybe čia turi ne vieną, bet keletą pasirinkimo galimybių tiek dèl aukščiausią valdžią vietos savivaldybẻje vykdančių subjektų, tiek ir dẻl tokiu būdu spręstinų vietos (viešųjų) reikalų identifikavimo:

2.1) gali būti nustatyta, kad aukščiausią valdžią tradiciškai vykdys savivaldybès bendruomené pati (vietinio sprendžiamojo referendumo ir / ar savivaldybès bendruomenès narių visuotinio sprendžiamojo susirinkimo formomis) ar per savivaldybès taryba (asamblèją), pastarajai posėdžių metu priimant reikšmingus visai vietos savivaldybei sprendimus. Tačiau galimas ir kitoks variantas - aukščiausią valdžią vykdančiu subjektu gali būti pasirinktas tik vienas iš minètųjų subjektų: pvz., aukščiausia valdžia gali būti ịgyvendinama tik per savivaldybès tarybą (asamblèją), kas, manytina, ir yra teisiškai ịtvirtinta Lietuvoje dabartiniu metu;

2.2) gali būti nustatyta, kad aukščiausią valdžią vykdantis subjektas gali priimti sprendimus, sprendžiant (tvarkant) visus vietos (viešuosius) reikalus. Tačiau valstybẻ gali apriboti aukščiausią valdžią vykdantị subjektą, suteikdama jam teisę galutinį žodị tarti sprendžiant (tvarkant) tik dali vietos viešųjų reikalų (pvz., konkrečiai nurodant visus tokius vietos (viešuosius) reikalus arba, atvirkščiai - nustatant, kokių reikalų iš visų vietos savivaldybės kompetencijai priklausančiųjų vietos reikalų toks subjektas spręsti negali).

\section{Išvados}

1. Interpretuojant Lietuvos Respublikos Konstitucijos 119 straipsnio 1 dalies nuostatą "Savivaldos teise laiduojama įstatymo numatytiems valstybès teritorijos administraciniams vienetams, igyvendinama per atitinkamas savivaldybiu tarybas", iki šiol yra tinkamai neatsakyta ị klausimą, kuriam iš subjektų yra laiduojama ir priklauso (vietos) savivaldos teisè: valstybès teritorijos administraciniam vienetui? (Vietos) savivaldybès bendruomenei? (Vietos) savivaldybès atstovaujamajai institucijai (atstovaujamosioms institucijoms)? Ar iš tiesų vienintelè vietos savivaldybès institucija, per kurią igyvendinama (vietos) savivaldos teisè, yra savivaldybès taryba?

2. Sisteminè nuostatų dèl (vietos) savivaldos teisès laidavimo ir ịgyvendinimo, nustatytų Lietuvos Respublikos Konstitucijoje, Lietuvos Respublikos Konstitucinio 
Teismo nutarimuose ir sprendimuose, Lietuvos Respublikos vietos savivaldos įstatyme ir Europos vietos savivaldos chartijoje, analizė leidžia teigti, kad: a) (vietos) savivaldos teisès subjektu Lietuvoje gali būti laikomi net trys subjektai, b) konstitucinès vietos savivaldos doktrinos kūrèjai (vietos) savivaldos teisès subjektu pasirinko teritorinę (vietos) bendruomenę, pritaikę analogiją (Konstitucijoje nustatyta, kad suverenitetas priklauso Valstybės Tautai), c) konstitucinès vietos savivaldos doktrinos kūrẻjai (vietos) savivaldos teisès subjektą prilyginę Valstybès Tautai (suverenui, kuriam priklauso aukščiausia galia valstybejje), analogiją pritaikè ir dèl (vietos) savivaldos teisès igyvendinimo: negalèdami atitrūkti nuo „griežtai suformuluotos“ Konstitucijoje ịtvirtintos nuostatos, kad savivaldos teise igyvendinama per atitinkamas savivaldybiu tarybas, (vietos) savivaldos teisès įgyvendinimą iš esmès sutapatino su aukščiausios valdžios vietos savivaldybejje vykdymu tik per atstovaujamąją savivaldybès (savivaldos) instituciją.

3. Teigtina, kad Lietuvoje, kuri priklauso šalims, kuriu teisinè sistema kontinentinè ir kurioje, aiškinant vietos savivaldybių kilmę, vietos savivaldos esmę ir turini, vadovaujamasi teisinès valstybės požiūriu ir dualinės vietos savivaldos teorija, teisé savarankiškai spręsti (tvarkyti) vietos reikalus (arba kitaip - (vietos) savivaldos teisè platesne prasme) laiduojama vietos savivaldybei - iš įstatymo nustatyto valstybės teritorijos administracinio vieneto nuolatinių gyventojų sudarytam teritoriniam organizuotam viešojo juridinio asmens statusą ir valstybès nustatytą (apibrèžtą) kompetenciją turinčiam socialiniam dariniui.

4. Savivaldos teisès laidavimas valstybès teritorijos administracinio vieneto nuolatiniams gyventojams (kaip teritorinei natūraliai bendruomenei ar kaip tik atsitiktiniais socialinio bendravimo ryšiais susijusių žmonių mechaninei visumai) yra ne vienkartinis valstybės aktas, bet tam tikrą apibrèžtą laiką trunkantis procesas. Šio proceso metu vyksta ženklūs, kokybiniai pokyčiai valstybės teritorijos administracinio vieneto nuolatinių gyventojų gyvenime (tiksliau jų bendravime, jų valdyme) ir tam tikrų valstybės priimamų sprendimų ir veiksmų dèka atsiranda (tiksliau - yra sukuriamas) teritorinis organizuotas teisinị statusą ir valstybės apibrèžtą kompetenciją turintis socialinis junginys (vietos savivaldybė).

5. Kūrybiškai taikant analogiją, teigtina, kad: a) vietos savivaldybei priklausanti savivaldos teisé ((vietos) savivaldos teisè platesne prasme) yra teritorinès organizuotos bendruomenès (vietos savivaldybès) teisè ir reali galia būti ir egzistuoti (reikštis) kaip teisiškai nepriklausomas, savivaldus ir savarankiškas socialinis darinys; šiuo atveju (vietos) savivaldos teisès (platesne prasme) subjektas yra vietos savivaldybė ir b) savivaldybès bendruomenei priklausanti savivaldos teisé ((vietos) savivaldos teisé siauresne prasme) - yra savivaldybės bendruomenės kaip ypatingo vietos savivaldybès struktūrinio elemento teisè valstybès nustatytomis organizacinemis formomis tiesiogiai ar per vietos savivaldybès tarybą (vietos savivaldybẻs atstovaujamąją instituciją) vykdyti aukščiausią valdžią vietos savivaldybeje, sprendžiant (tvarkant) vietos savivaldybès kompetencijai priskirtus vietos (viešuosius) reikalus; šiuo atveju (vietos) savivaldos teisė kaip aukščiausios valdžios vietos 
savivaldybeje teisè priklauso savivaldybès bendruomenei ((vietos) savivaldos teisès (siauresne prasme) subjektas yra savivaldybès bendruomenė).

6. Teigtina, kad (vietos) savivaldos teisès igyvendinimas yra sietinas su subektais, kuriems priklauso (vietos) savivaldos teisè, ir su tokių subjektų veikla, igyvendinant jiems suteiktas teises ir pareigas tam tikrose veiklos srityse. Todèl a) (vietos) savivaldos teise kaip visai vietos savivaldybei (teritorinei organizuotai teisini statusą ir valstybės apibrèžtą kompetenciją turinčiai bendruomenei) priklausanti teisė yra ịgyvendinama per visus šị sudètingą socialinị junginị sudarančius vidinius elementus ir b) (vietos) savivaldos teisę kaip savivaldybės bendruomenei priklausančią teisę vykdyti aukščiausią valdžią savivaldybės bendruomenè igyvendina pati (tiesiogiai) arba per savivaldybès atstovaujamąją instituciją - savavaldybès tarybą (asamblèją), sudaromą demokratinių rinkimų būdu.

\section{Literatūra}

1. Astrauskas A. Vietos savivaldos samprata ir savivaldybès institucinè struktūra. Mokomasis leidinys. Pirma dalis. Vilnius: Lietuvos teisès universitetas, 2003.

2. Astrauskas A. Vietos savivaldos raida Lietuvoje 1990-2010 metais. Viešoji politika ir administravimas. 2011, 2, 283-298.

3. Astrauskas A. Vietos savivaldos raida Lietuvoje nuo $1990 \mathrm{~m}$. iki dabar. Viešoji politika ir administravimas. 2013, T. 12 (2), 260-271.

4. Biržys R., Jasmontas A., Kačerauskas T. ir kt. Filosofijos pamatai. Mokomoji knyga. 2-oji laida. Vilnius: Technika, 2007, 221-224.

5. Europos vietos savivaldos chartija. Valstybės žinios. 1999, Nr. 82-2418.

6. Jankauskas K. Vietos savivalda. Lietuvos konstitucinè teisè. Vadovèlis. Vilnius: Mykolo Romerio universitetas, 2012, 821-840.

7. Legkauskas V. Grupių formavimosi mechanizmas. Socialinè psichologija. Vilnius: Vaga, 2008, 319-331.

8. Lietuvos Respublikos Konstitucija. Oficialių dokumentų tekstai su pakeitimais ir papildymais iki 2010 m. kovo 1 d. Kaunas: UAB ,Judex“, 2010.

9. Lietuvos Respublikos Konstitucinio Teismo 2002 m. gruodžio 24 d. nutarimas. Valstybès žinios. 2002, Nr. 103-4605.

10. Lietuvos Respublikos Konstitucinio Teismo 2010 m. kovo 21 d. nutarimas. Valstybès žinios. 2010, Nr. 85-1605.

11. Lietuvos Respublikos vietos savivaldos pagrindų įstatymas. Valstybės žinios. 1990, Nr. 7-170.

12. Lietuvos Respublikos vietos savivaldos ịstatymas. Valstybės žinios. 1994, Nr. 55-1049.

13. Lietuvos Respublikos vietos savivaldos įstatymas. Valstybès žinios. 2000, Nr. 912832 .

14. Lietuvos Respublikos vietos savivaldos įstatymas. Valstybės žinios. 2008, Nr. 1134290.

15. Romeris M. Visuomenè: sąvoka ir klasifikacija. Valstybè ir jos konstitucinè teisè. Pirma dalis. Valstybė. II tomas. Vilnius: Pradai, 1995, 74-96. 
16. Šileikis E. Teritorinès (vietos) savivaldybès. Alternatyvioji konstitucinè teisè. Vilnius: Teisinès informacijos centras, 2005, 259-290.

17. Zakarevičius P. Vadyba: genezè, dabartis, tendencijos. Kaunas: Vytauto Didžiojo universiteto leidykla, 1998, 85-111.

18. Vaitiekienė E., Vidrinskaitė S. Mokymo apie valstybę pagrindai. Lietuvos konstitucinès teisès ịvadas. Vilnius: Justicia, 2001, 126-134.

\title{
Algirdas Astrauskas
}

\section{Who Is Granted the Right to Self-Government in Lithuania and who Implements This Right and how?}

\begin{abstract}
There are many research papers on local self-government from 1990s till present in Lithuania. However, according to the author, there is a lack of research papers where the Lithuanian local self-government system would be analysed systematically. The author has published several articles in the academic journal Public Policy and Administration. In this article, the author, by way of creative analogy, presents his approach as to who is granted the right to (local) self-government and who enjoys this right (i.e., what is the subject of the right to (local) self-government) as well as explains who, in his opinion, enforces the right to (local) self-government and how.

Summarizing the results, the author presents the following conclusions:

1. Interpreting the first paragraph of Article 119 of the Constitution of the Republic of Lithuania "The right to self-government shall be guaranteed to administrative units of the territory of the State, which are provided for by law. It shall be implemented through corresponding municipal councils", the following questions remain unanswered: what subject is guaranteed (granted) the right to (local) self-government? Is a municipal council really the only local authority through which the right to (local) self-government is implemented?

2. The systematic analysis of provisions on guaranteeing (granting) and implementing the right to (local) self-government, established in the Constitution of the Republic of Lithuania, rulings and decisions of the Constitutional Court of the Republic of Lithuania, the Republic of Lithuania Law on Local Self-Government, and the European Charter of Local Self-Government, suggests that: (a) three subjects may be considered as the subjects of the right to (local) self-government in Lithuania; (b) the developers of the constitutional doctrine of (local) self-government chose the territorial (local) community as the subject of the right to (local) self-government by applying analogy (the Constitution stipulates that sovereignty belongs to the Nation); (c) by making the subject of the right to (local) self-government equal to the Nation State (sovereign that has the supreme power in the state), the developers of the doctrine applied the analogy in respect of the implementation of the right to (local) selfgovernment: they essentially saw the implementation of the right to (local) self-government and exercise of the supreme power in the municipality as the same, the latter being exercised through the representative municipal (self-government) institution.

3. It is stated that in Lithuania, which belongs to the countries with the continental legal system and where the theory of dual local self-government is followed for interpreting the origin of local municipalities and the nature and content of local self-government, the right to independently deal with local matters (or otherwise, right to (local) self-government in a
\end{abstract}


wider sense) is guaranteed (granted) to the local municipality, an organised territorial social body that is composed of permanent residents in a territorial administrative unit established by law, that has the status of a public legal person and that has the competence established (defined) by the state.

4. Guaranteeing (granting) the right to self-government to the residents of the territorial administrative unit is a process lasting for a defined time rather than a single action of the state. During the process, major qualitative changes take place in the life of residents (to be accurate, in their communication and their governing) of the territorial administrative unit, and some decisions adopted and actions taken on the national level give shape to a territorial, organised social body (local municipality) that has a legal status and the competence defined by the state.

5. Creatively applying the analogy, it may be asserted that: a) the right to self-government (right to (local) self-government in a broader sense) belonging to a local municipality is the right of a territorial organised community (local municipality) and the real power to exist (act) as a legally independent, self-governing and autonomous social body; in this case, the subject of the right to (local) self-government (in a broader sense) is a local municipality, and (b) the right to self-government (right to (local) self-government in a narrower sense) belonging to a municipal community is the right of a municipal community as of a special local municipal structural element to directly or through a municipal council (representative body of a local municipality) exercise, in the ways prescribed, the supreme power in the local municipality when dealing with local (public) matters within the competence of the local municipality; in this case, the subject of the right to (local) self-government (in a narrower sense ) is a municipal community.

Algirdas Astrauskas - Mykolo Romerio universiteto Politikos ir vadybos fakulteto Viešojo administravimo instituto docentas, socialinių mokslų daktaras.

E. paštas algirdas.astrauskas@1rs.1t

Algirdas Astrauskas, Mykolas Romeris University, Faculty of Politics and Management, Institute of Public Administration, Assoc. Prof.

Itteiktas 2014 m. rugsèjo mėn.; recenzuotas; parengtas spausdinti lapkričio mėn. 